\title{
"Ele foi meu muro": Liberdade artística e liberdade narrativa em uma metaentrevista pública
}

\author{
"He was my wall": Artistic freedom and narrative freedom in a \\ meta-interview
}

Resumo:

Neste artigo, analiso uma entrevista de história oral produzida no contexto de um projeto de pesquisa com cantoras negras brasileiras cujas trajetórias artísticas foram marcadas pela não adesão ao samba como gênero musical definidor. A entrevista aqui apresentada e discutida não consiste, porém, em um relato de experiência, mas sim em uma "metaentrevista" na qual uma das participantes do projeto, a cantora Adyel Silva, reflete sobre a experiência de narrar sua vida para um escutador específico, o pesquisador de história oral. Tem-se, a partir dessa metaentrevista, a rara oportunidade de discutir aspectos ligados à interação entre pesquisador e entrevistado, à apresentação pública de histórias privadas, ao exercício da liberdade narrativa, ao processo criativo de narração de si e de cristalização de narrativas, ao papel que as entrevistas desempenham na vida e no projeto de nossos entrevistados.

Palavras-chave

História oral; Narrativas pessoais; Liberdade narrativa

\section{Abstract:}

In this article, I analyze an oral history interview recorded in the context of a research project on Brazilian black women singers whose careers are distinguished by their refusal to embrace samba as the sole musical genre they perform. The interview presented and discussed here, however, is not as much an account of experience but rather a "meta-interview"

\footnotetext{
${ }^{1}$ Professor do Departamento de Desenvolvimento Humano e Reabilitação da Universidade Estadual de Campinas. Doutor em História Social (USP, 2013) e pós-doutor em História (UFF, 2015). Pesquisador do Grupo de Estudo e Pesquisa em História Oral e Memória (GEPHOM/EACH-USP), do Laboratório de História Oral e Imagem (LABHOI-UFF) e do Centro de Estudos em Música e Mídia (MusiMid).
} 
in which one of the participants of the project, the singer Adyel Silva, reflects on the experience of narrating her life to a specific listener, the oral history researcher. Drawing on this meta-interview, we have the rare opportunity to discuss aspects related to the interaction between researcher and interviewee, the public presentation of private stories, narrative freedom, the creative process of narrating oneself and crystallizing narratives, the role that oral history interviews play in thelives and projects of our interviewees.

\section{Keywords}

Oral history; Personal narratives; Narrative freedom

\section{Introdução}

Em abril de 2009, alguns colegas e eu, então estudantes de pós-graduação na Universidade de São Paulo, tivemos notícia de que em 16 de maio daquele ano seria celebrado o Dia Internacional das Histórias de Vida, em sua segunda edição. Decidimos nos engajar na celebração - cientes de que ela era altamente controversa. Para nós, a efeméride funcionou como um pretexto para darmos forma a algumas ideias que já nutríamos. À medida que avançamos na proposta de um evento, o painel artístico que eu havia planejado inicialmente cedeu lugar a outra realização, mais desafiadora e menos exigente em termos práticos: uma "metaentrevista pública".

Semanas antes eu havia finalizado as gravações para meu projeto de história oral com "cantoras negras brasileiras não sambistas". Há três anos vinha conduzindo entrevistas longas e múltiplas, de história de vida,problematizando visões estereotipadas que sugeriam uma falsa equivalência entre artista negro e sambista. Havia também coletado uma profusão de canções populares que incorporavam a ideia de uma habilidade ou inclinação "natural" de mulheres e homens negros para o samba e estereótipos correlacionados, no interior desses textos, a esse gênero musical: a sensualidade, o ritmo, a força física, a genuinidade/autenticidade, a simplicidade, a destreza manual. Aquelas longas entrevistas foram a base para a minha dissertação de mestrado Entre a harmonia e a dissonância: História oral de vida de cantoras negras brasileiras e para meu livro Solistas dissonantes: História (oral) de cantoras negras, ambos de 2009 - trabalhos de mesma inspiração e origem, mas sensivelmente diferentes

Revista Memória em Rede, Pelotas, v.10, n.18, Jan./Jul.2018 - ISSN- 2177-4129 


\section{We memória}

entre si. Imerso no processo de preparação desses textos, pensei em quão fascinante seria ter a visão do outro - do entrevistado - sobre esse processo.

Nós, pesquisadores de história oral, educamos nossas sensibilidades para devotar aos nossos narradores atenção e cuidado intensos durante o processo de entrevista. Muitas vezes mimetizamos essa atenção no produto de nosso trabalho, oferecendo centralidade às histórias que colhemos. A narrativa sobre o processo, entretanto, continua sendo nossa.

As visões de nossos narradores sobre a experiência de ser escutado são histórias que não colhemos. Vez ou outra, projetos que tratam de casos traumáticos ou assuntos delicados, com pessoas em circunstâncias extraordinárias ou em situações-limite, resvalam nessa experiência, ainda que de maneira bastante especulativa. Igualmente, colocações sobre o aspecto "curativo" ou "terapêutico" da entrevista de história oral costumam basear-se mais em suposições do que em empiria. Nem sempre nossos entrevistados nos dizem, no ato mesmo da entrevista,algo como: "Não se preocupe, não é a questão de rasgação de seda, não. A questão é como eu me senti. Fui bem acolhida pelo modo como conversaram comigo. Acho que isso é o mais importante", palavras de uma entrevistada num projeto de histórias orais com mulheres vivendo com AIDS (KIND, CORDEIRO, 2016, p. 116).

Em circunstâncias usuais, temos poucas condições para explorar a visão dos narradores sobre a experiência de narrar. O contato com eles nem sempre se estende para além da realização da própria entrevista. Algumas vezes alimentamos essa conexão só até que Ihes enviemos uma cópia da gravação, da transcrição ou do trabalho finalizado. O retorno deles, quando oferecido, pode ser positivo ou negativo - e nesse sentido, sim, encontramos na literatura especializada relatos de casos em que os entrevistados manifestam se identificar ou não com o produto da pesquisa (e muitos de nós temos a experiência de ouvir nossos entrevistados comentarem casualmente essas reações).

O psicólogo John Kotre (2013) está entre aqueles que comentaram a atitude de seus sujeitos diante das narrações autobiográficas que produziram. Uma mulher lhe disse que se sentia como "se estivesse sem roupa e suspensa em uma cerca para todos verem"; outra afirmou que "era como se olhar em um espelho". Segundo Kotre, elas

Revista Memória em Rede, Pelotas, v.10, n.18, Jan./Jul.2018 - ISSN- 2177-4129 


\section{memória}

estavam "espantadas e admiradas de ver tanto delas mesmas em um papel" e sua reação foi de "encobrir o que foi exposto" - reação entendida por ele como um tipo de confirmação à "verdade narrativa" da história contada. No caso de um outro relato autobiográfico, assinalado pela sensação de fracasso pessoal, o padrão de confirmação foi o mesmo, levando o narrador a escrever, um ano depois: "Sou eu o homem retratado nesse livro? Provavelmente... E eu desejaria não sê-lo" (KOTRE, 2013, p. 33).

Nós mesmos, praticantes de história oral, ficamos entusiasmados em oferecer nosso ponto de vista sobre as ocasiões em que os microfones se invertem. Ser entrevistado para um projeto sobre o movimento estudantil na Califórnia correspondeu, para Richard Cándida Smith (2011), a uma oportunidade de aprimorar suas visões sobre o papel da hermenêutica na interpretação de fontes orais. "A experiência de estar do outro lado do gravador foi para mim tão intensa, que desafiou alguns dos meus preconceitos sobre como o processo se desenvolve", escreveu (p. 155). Chiara Vangelista (2008), depois de ver o resultado de uma entrevista concedida a uma colega antropóloga sobre os problemas com a amamentação para uma mulher que trabalha, teve também uma reação de estranhamento: "Eu li, mas não reconheci nada do que estava escrito. Tinha na minha memória que havia feito um outro percurso em relação à amamentação. (...) Mesmo sendo historiadora e tendo prática com a entrevista, não me identifiquei com aquele texto" (p. 18). Carla Mühlhaus (2007), jornalista que tem a escuta atenta como seu instrumento, ficou igualmente surpreendida com o produto de uma entrevista coletiva que concedeu a alunos de jornalismo. Ali, ela percebeu o caráter "revelador" de uma entrevista, que impele o narrador a organizar seu pensamento. "Daí o meu susto ao ler o resultado da entrevista e perceber nela o ganho de clareza alcançado por ideias antes confusas" (p. 312), afirmou.

Não é nada fácil encontrar esse tipo de avaliação vindo de entrevistados que não têm o diálogo como paixão e ofício - já que isso implicaria um investimento na reflexão metodológica feito não só pelo pesquisador, mas também pelos seus sujeitos. Para começar, tendemos a privilegiar, em nosso elenco de entrevistados, aqueles que menos registros deixaram sobre suas histórias de vida; como esperar que eles deixem registros, também, sobre o processo de narrar essas histórias? Exceções só acontecem quando o grau de comprometimento das partes nessa relação intersubjetiva é grande a ponto de se

Revista Memória em Rede, Pelotas, v.10, n.18, Jan./Jul.2018 - ISSN- 2177-4129 


\section{memória}

consubstanciar em um nível mais profundo de colaboração - como o que aconteceu entre a historiadora Catherine Fosl (2006) e a ativista Anne Braden na preparação da biografia desta última, um livro que se encerra com a transcrição de um interessante diálogo sobre a experiência de estar em lados opostos de uma experiência colaborativa. "Quero deixar claro que este é o seu livro, não o meu. (...) Você tentou incluir meu ponto de vista e eu sou grata por isso. Mas eu penso que este livro teria sido muito diferente se nós o tivéssemos escrito juntas" (p. 337), diz a biografada, ressaltando o fosso existente entre a interpretação das duas, mesmo após um trabalho intenso de colaboração.

Stephen Sloan (2012), criticou o descaso dos pesquisadores e o abafamento da experiência do narrador dentro das reflexões consolidadas no campo da história oral. A busca dele pela perspectiva de quem narra foi motivada por um problema prático: uma mulher não autorizou que o programa de história oral em que ele trabalha inserisse sua entrevista, gravada alguns anos antes, na coleção de acesso público. "Essa é a história dele, não a minha", ela se justificou, referindo-se a um estudante que a havia entrevistado como parte das tarefas de uma disciplina. Sloan sugere que a pouca atenção oferecida à visão do entrevistado decorra talvez da suposição tácita de que este tem um papel que é relativamente passivo na entrevista: os próprios termos empregados (entrevistador/entrevistado) denotariam a consideração distinta de tais papeis: ao entrevistador caberia a ação; ao entrevistado a reação.

Há razões mais práticas: o entrevistador pode temer escutar (quanto mais divulgar!) o que pensa o entrevistado sobre seu próprio trabalho; pode recear que a transformação de seu próprio proceder em assunto seja entendida como a manifestação de uma torta vaidade; pode preferir refrear-se em vez de expor a um debate procedimental quem já se expôs contando sua história de vida. Naquela ocasião, em 2009, parecia oportuno arriscar: para entender melhor como o processo de pesquisa em história oral é visto por nossos entrevistados, pedi a uma pessoa com quem tive uma intensa relação durante a investigação que contasse como era a vista do lado de lá.

\section{2. "Eu estava lá"}

Revista Memória em Rede, Pelotas, v.10, n.18, Jan./Jul.2018 - ISSN- 2177-4129 
A protagonista da "metaentrevista pública" era Adyel Silva, artista brasileira que começou a atuar profissionalmente nos anos 1980, tornando-se uma atriz/cantora celebrada em função de sua participação na primeira montagem de Emoções baratas, musical icônico de José Possi Neto, e, mais tarde, de sua gravação de / FeelGood, canção de Hilton Raw que serviu como trilha para um comercial da grife de jeans Jeaneration - que se inscreveu na história da publicidade televisiva brasileira por se constituir em uma espécie de videoclipe com três minutos de duração. A peça, em sua constituição tanto sonora quanto imagética, inscreveu-se também nas histórias pessoais dos que a viram, e ainda hoje funcionam como detonadores emocionais, como revelam vários comentários postados no YouTube.

O convite a Adyel não foi feito por acaso. Eu a conhecia há cinco anos, desde 2004, quando ela havia lançado o CD Chic da Silva, que resenhei para um site com o qual colaborava. Em meu blog pessoal, comentei que não parava de escutar o disco - e foi assim que nos conhecemos, antes que eu fosse a um show seu, no mesmo ano. Em 2006, a procurei para o projeto; ela aceitou participar prontamente e marcamos um primeiro encontro em sua casa. Foi a primeira dentre as cantoras negras que entrevistei. Gravamos por cerca de doze horas, ao longo de um ano, e conversamos por muitas outras horas, e trocamos centenas de mensagens, e compartilhamos muitas canções, informações e planos.Algumas semanas antes de nosso encontro público, eu havia entregado para Adyel o texto editado de sua entrevista, que ela me devolveu, com pequenas modificações, naquele mesmo dia. $O$ conjunto de suas narrações, tocante $e$ complexo, emocionado e racionalizado, acabou funcionando como o "chão" do meu trabalho: é a entrevista que o abre, sinalizando questões que são retomadas ao longo de todo o texto.

Mesmo assim, foi uma aposta no escuro. Em nossos encontros privados Adyel tinha se revelado, sem dúvida, parte daquela comunidade rara de "narradores plenos" (HOLANDA, 2009), capazes de transmitir com paixão e afinco suas memórias pessoais. Mas, em público? E, ainda mais, uma entrevista sobre o processo de ser entrevistada, uma entrevista sobre entrevistas?

$\mathrm{Na}$ manhã de nosso encontro público, gastei menos de dez minutos para apresentar Adyel e o projeto de pesquisa para uma plateia de cerca de 150 pessoas.

Revista Memória em Rede, Pelotas, v.10, n.18, Jan./Jul.2018 - ISSN- 2177-4129 


\section{memón ória}

Adyel falou por mais uma hora, provocando na audiência uma gama de reações. Contundente, falou da conflituosa relação com o passado que sua condição - como cantora, negra, mulher - impõe. Discutiu de maneira original e imprevista aspectos críticos de uma relação estabelecida no contexto de um projeto de pesquisa acadêmico. Antes de ser intensamente aplaudida de pé, cantou acapella, a pedidos, uma canção. Escolheu Brasil Pandeiro, de Assis Valente, que adaptou: "Brasil, esquentai vossos pandeiros, iluminai os terreiros, que nós queremos contar".

Todos os CDs que Adyel havia levado ao evento (eu pedi que ela o fizesse, mas ao vê-la com uma caixa com 25 discos suspeitei que me faltava tino comercial) e uma lista de encomendas foi providenciada. Recebi vários convites para palestras e oficinas de história oral vindos de pessoas da plateia. Até hoje, em eventos de nossa área, há quem me encontre e faça questão de dizer: "Eu estava lá". Uma dissertação de mestrado em comunicação, defendida na ECA-USP, sobre storytelling, baseou-se na nossa conversa. Aquele foi um momento impactante e revelador - para mim, para Adyel, e para o público, todos participantes de um encontro sublime que nos manteve em sintonia total por mais de uma hora, numa manhã ensolarada de sábado.

Muito se deve não apenas ao que foi falado, mas a como. Adyel é uma excelente oradora. Sua forma de falar cativante, sua performance em cena, sua capacidade de rir de si mesma, seus gestos insinuantes, seus olhares, suas meias palavras. Ela trouxe tudo isso para uma performance pública, criando uma ambiência que acrescentou camadas de significado à sua narração. A consciência nítida de Adyel sobre o projeto em que ela estava inserida foi fundamental para que a sessão não se destacasse do conjunto do evento, transformando-se num "show" desconectado das demais atividades de nossa jornada acadêmica. Ao contrário, ouvi de um participante a seguinte expressão: "Tudo o que aprendi sobre colaboração em história oral foi materializado ali, naquele instante”.

"Aquele instante" de 70 minutos me ensinou muito sobre intersubjetividade, colaboração, identificação, compromisso, ética em pesquisa, linguagem, emoção... Neste texto, trato de alguns desses aspectos, valendo-me dos preciosos insights oferecidos por Adyel sobre sua experiência enquanto entrevistada: o papel do público na reconfiguração narrativa; a relação entre liberdade artística e liberdade narrativa; a cristalização de fragmentos narrativos; a revitalização do passado familiar.

Revista Memória em Rede, Pelotas, v.10, n.18, Jan./Jul.2018 - ISSN- 2177-4129 


\title{
3. Uma história oral em público
}

Uma entrevista implica, sempre, uma transição do privado para o público; mira a apresentação pública de histórias privadas. À exceção daquelas orientadas para o sujeito (a entrevista psicológica, a entrevista de emprego), as entrevistas visam em última instância cruzar o limiar que separa público e privado. ${ }^{2}$ Sendo assim, o público - esteja ele corporalmente presente ou imaginado - é um fator determinante, que interfere na narração. $^{3}$

Mais do que triangular uma relação preexistente, a inusitada situação comunicativa daquele sábado requalificou a função de cada um desses polos. Implicou, inclusive, propor uma nova relação com o público: a relação que o artista desenvolve com ele baseia-se na aspiração de encantá-lo, de atrair sua atenção. Ali, tratava-se de um outro público - tão heterogêneo quanto a audiência de um espetáculo, mas elaborado em função do interesse na história oral, do gosto pela escuta e também pelo questionamento. Seu pendor não era contemplativo, mas inquisitivo.

O papel definidor do público ficou claro logo após minha primeira pergunta. Depois de introduzir brevemente (já que esse não era, a rigor, o tema do encontro) o projeto que eu conduzia e o lugar da narrativa da Adyel dentro dele, lancei minha primeira questão:

\begin{abstract}
Antes de eu te procurar para a entrevista, já existia a sensação de pertencer ao grupo, de conversar - artisticamente ou em termos de história de vida - com outras cantoras negras? Em que universo musical você se insere e como você se define artisticamente em relação às outras cantoras?
\end{abstract}

"Posso ficar horas aqui falando", Adyel respondeu, olhando para mim. Mas, imediatamente, voltou-se para a plateia:

\footnotetext{
${ }^{2}$ Linda Shopes sugeriu a vivaz imagem da entrevista de história oral como um protótipo da história pública: uma "história pública a dois", que consiste em "um diálogo sobre o passado entre um historiador e um membro do público, ou, talvez dizendo melhor, entre duas pessoas com tipos diferentes de conhecimento histórico" (2016, p. 71).

${ }^{3}$ Em um ensaio sobre "liberdade narrativa", a que aludirei adiante, Robert Zussman (2012) aponta que uma das dimensões que distinguem as narrativas é "autoridade da audiência": "em alguns casos, a audiência (um policial, um padre, um médico) pode dirigir a narrativa" (p. 811). Ele opõe essas narrativas feitas "de cima para baixo" àquelas feitas "de baixo para cima", nas quais "pode haver uma audiência, mas sem autoridade sobre forma ou conteúdo". Bem, isso depende.
} 
É... Eu preciso começar dizendo que foi... assim... O Ricardo fez um papel de psicólogo. [voz embargada] Quando ele aparece na minha casa - você está vendo o que você está fazendo? [ela olha para mim; risos da plateia] -, quando ele me telefona...

A dinâmica discursiva de toda a entrevista foi um decalque desses poucos segundos: o público foi o interlocutor eleito de Adyel durante toda a hora que se seguiu; eu havia me convertido de destinatário a conteúdo da mensagem; minha presença era tão somente um estímulo; meu papel foi o de receptor de comentários colaterais que serviam para ampliar a dramaticidade ou conferir autenticidade à narrativa de Adyel. Dentro dessa lógica, aquela primeira pergunta foi naturalmente ignorada.

No começo, ela narrou nossa relação, problematizando-a. Introduziu o tema do projeto em nossas próprias histórias pessoais. Alternando passagens altamente dramáticas com comentários leves e bem-humorados, rapidamente cativou o público. Depois do início comovido de sua narrativa, foi sobretudo para a espirituosidade que ela apelou: seus contos lancinantes marcados pela explicitação da consciência racial e de gênero tocavam a plateia da mesma forma como haviam antes me tocado. Só que nossas entrevistas foram graves, solenes (circundadas por momentos de descontração, mas sempre off the record); a nova entrevista foi invariavelmente entremeada pelo bom humor.

"Você está vendo o que você está fazendo?", Adyel me pergunta (como que para contrabalançar o caráter sensacional de sua voz embargada), mas a resposta vem do público. E é seu riso - atestado do êxito da alternância entre o trágico e o cômico - que será perseguido. Como o linguista Neal R. Norrick (2006) escreveu, "a apresentação de eventos constrangedores, dolorosos e até ameaçadores em narrativas bem-humoradas oferece evidências cotidianas atraentes de como as memórias são reconstruídas para uma audiência específica, em um contexto específico" (p. 85). É nessa matriz que Adyel inscreve sua segunda autoconstrução. O humor, virtualmente ausente de nossas conversas privadas, resplandece em sua narrativa pública:minhas expressões faciais circunspectas podiam bastar como feedback sob um foco de luz em sua sala de estar, mas, em um amplo auditório, os risos sonoros da audiência eram mais apropriados.

\footnotetext{
${ }^{4}$ Exceto quando indicado, todas as citações provêm da entrevista pública realizada em 16 de maio de 2009, na Universidade de São Paulo.
}

Revista Memória em Rede, Pelotas, v.10, n.18, Jan./Jul.2018 - ISSN- 2177-4129 
Nessa mesma chave, Adyel rememorou a maneira inusitada pela qual nos conhecemos, reintroduzindo, em nossas histórias pregressas, o mote do projeto:

\begin{abstract}
Quando saiu meu disco, foi um processo muito complicado e muito difícil, porque eu não sou uma cantora de samba e a impressão que eu tenho é que o Brasil enxerga as cantoras brasileiras negras como cantoras sambistas - e se você não é [cantora de samba] você não existe, ou (...) pra se afirmar (...) o caminho é muito mais cheio de pedras, é muito mais comprido e tal... Bom, o disco saiu... (...) Aí então eu entro no Google, boto lá AdyelChic da Silva, entre aspas, e uma das coisas que aparece é esse comentário: "Não consigo parar de ouvir. Não consigo tirar esse disco do meu toca-CD". Aí eu fui lá ver quem era. Deixei um recado pra ele e a gente começou a trocar uma coisa até tímida, não foi? [dirigese a mim] Coisa assim... [Depois] eu fiz um lançamento no SESC Vila Mariana e convidei o Ricardo. E, Ricardo, agora eu vou te confessar: [risos da plateia] eu fiquei morrendo de vergonha porque, é claro, você está fazendo um show, você está lidando com pessoas que têm emoções e tal. Aí é assim: é uma guitarra que você percebe que deu a nota errada, e por causa dela talvez eu tenha dado a nota errada, e todo mundo se atropelando... E eu falando assim: "Meu Deus, do que eu vi desse menino, ele conhece música, ele gosta de música". Eu queria fazer o meu melhor naquela hora. E não saiu o meu melhor. Eu falei: "Ai, que vergonha, que chato..." [risos da plateia]
\end{abstract}

Mais uma vez - indo ao encontro do que Norick (2006, p. 93) observa -, a avaliação crítica do passado, de um ponto de vista diferente - o do presente - abre caminho para um relato bem-humorado. Minhas próprias lembranças do show - do qual me lembro em detalhes - eram as melhores, mas já não cabia interromper: aquelas não eram as minhas lembranças, mas as de Adyel. E elas já haviam conquistado o seu público - ironicamente, com o relato espirituoso de um episódio que, nem em nossas entrevistas formais nem em nossas incontáveis conversas, havia aparecido. De certa forma, isso confirma que o plano arriscado de pedir a um narrador que contasse sobre o processo de narrar deu certo: em forma (do solene ao tragicômico ou ao "nem trágico nem cômico") e conteúdo (a discussão da nossa relação e do nosso processo), dali até o final do encontro, a performance de Adyel ofereceu insights eloquentes para a maneira como nossos entrevistados interpretam e se relacionam com nossas pesquisas.

\title{
4. Liberdade, liberdade
}


Naquela ocasião, economizei perguntas. A fala de Adyel - como em nossas entrevistas - seguiu rumo próprio. Depois de contar como havíamos nos conhecido, ela emendou:

\begin{abstract}
Enfim... Aí um pouco depois o Ricardo me liga timidamente, fala desse... do quê que ele pretendia desse projeto dele e eu falei: "Tudo bem! Vem, vem conversar. Vamos conversar, vamos conversar. Aí ele chega em casa. [pausa] Entra. [pausa] Senta. [pausa] Tira um gravador. [risos da plateia]. E ele fez: "Faaaala..." [risos da plateia] Eu falei: "Meu Deus do céu!" Em tantos... nesses anos todos de carreira é claro que não era a primeira vez que eu estava sendo entrevistada. Mas era uma entrevista diferente. Porque uma coisa é um jornalista te ligar ou pessoalmente te perguntar: "Quando é que você começou? O que é que você ouve? O quê que não-sei-o-que?”. Aquelas coisas que é só apertar um negocinho aqui e a resposta vai, porque é sempre... as pessoas não são brilhantes! [risos da plateia] É sempre a mesma porcaria de pergunta...
\end{abstract}

Outra vez, seu relato espirituoso pavimenta uma conclusão substanciosa:

E aí a total liberdade que a pessoa te dá de falar: "fala"... e a constatação de que a liberdade às vezes é uma coisa complicada. E você começar a falar, assim... (...)Você toma um susto, porque quando ele faz assim: "Fala..." - gente, liberdade é uma coisa perigosa! É isso: é uma coisa perigosa, uma coisa cara, e quando você se depara de frente, fala assim: "ahn?".

Uma coisa séria, "cara", "perigosa" - não apenas para a narradora.

Nós, praticantes de história oral, atribuímos um valor crítico à liberdade em nossa prática de pesquisa. Um dos princípios éticos que compartilhamos é o da liberdade que nossos sujeitos têm para decidir se, como, quando, contribuirão para nossa pesquisa. Prezamos igualmente a liberdade narrativa desses sujeitos: tendemos a compreender a entrevista de história oral não como um inquérito, mas como um espaço narrativo gerenciado cooperativamente pelas partes que o instituem e frequentam. Nesse espaço, os sujeitos têm ascendência sobre o conteúdo e sobre a forma de suas histórias, mesmo que elas surjam em resposta a um impulso externo (o nosso), e não de um ímpeto autobiográfico. Quando descrevemos nosso método, muitas vezes nos valemos da oposição à mesma imagem ativada por Adyel: a de um jornalista. ${ }^{5}$

\footnotetext{
${ }^{5}$ Embora, vale a pena frisar, haja vários tipos de jornalismo. O trabalho de pesquisa do jornalismo literário ou do jornalismo de grande extensão certamente guarda mais semelhanças com a nossa prática do que com a do noticiário. Nos últimos anos, Eliane Brum tem sido um exemplo notável disso.
} 
Em Solistas dissonantes, os sentidos de liberdade eram muitos, constelados à primordial liberdade artística - de quem "ousou" escolher as canções da sala de visita em vez do samba do quintal (sem juízo de valor). A liberdade, com suas implicações, foi um motivo estimulado e explorado nas entrevistas daquele projeto, inevitavelmente. $\mathrm{Na}$ entrevista de Adyel, a liberdade é um tema particularmente poderoso, que aparece como algo a ser constantemente perseguido, e posteriormente desfrutado. Trata-se da liberdade de escolha, da liberdade de ir e vir, da liberdade de conhecer, da liberdade de se expressar - narrada por Adyel como pulsão inexorável, mas limitada pelos condicionantes sociais, materializadas nas figuras dos detentores dos meios de produção, circulação, divulgação artística. Por ser, então, uma conquista, a difícil caminhada rumo à liberdade é narrada com orgulho. Um único exemplo, da entrevista publicada de Adyel:

\begin{abstract}
A única coisa que me consola é pensar que, quando o mundo acabar, eu vou para o paraíso, porque fiz a coisa certa! Vou ficar lá em cima, rindo e abrindo as asinhas - e ficar assistindo esses produtores, esses jabazeiros, esse povo que passa arrombando tudo, arder no fogo do inferno! De vez em quando vou rezar um pouco por suas almas... Mas só um pouquinho, claro! Deles eu não sinto pena; sinto pelas pessoas que não podem conhecer. (SANTHIAGO, 2009, p. 37)
\end{abstract}

Ocorre que, se a relação com a liberdade artística é pacífica, o mesmo não ocorre com a liberdade narrativa: a primeira é um assunto confortável (e talvez seja mesmo um topos recorrente em narrativas de artistas); a segunda é um pressuposto conflituoso: "a constatação de que a liberdade às vezes é uma coisa complicada", diz Adyel. O desconforto se dá porque, ao contrário da liberdade artística (que deve ser perseguida), a liberdade narrativa está ao alcance dos lábios, ao menos no contexto de uma entrevista de história oral.

Ao colocar em questão a liberdade narrativa, em um gesto que se contrapõe às suas visões sobre todos os outros tipos de liberdade, Adyel nos impede de relevar um comentário metodológico. Durante todo aquele projeto, minha estratégia para iniciar as entrevistas foi a mesma: eu retomava o tema do estudo;sinalizava genericamente o escopo que gostaria de cobrir na entrevista; esclarecia que não tinha uma pauta ou roteiro de questões. E concluía: "Você pode começar por onde você quiser, como quiser...". Na maior parte das vezes isso funcionou, mas uma experiência em que eu mesmo fui entrevistado deixou-me menos impaciente com a forma como as entrevistas começam, 
afastando-me assim do preceito de uma história oral "voluntarista", termo usado por Fabiola Holanda:

\begin{abstract}
o voluntarismo se dá porque é o colaborador que escolhe por onde quer começar a contar sua experiência (...) queremos que as narrativas tenham personalidade, que elas apresentem inícios diferentes, percursos de acordo com a trajetória da vida estabelecida a partir do contar do colaborador e não entrevistas onde se pode "adivinhar" as perguntas que cortaram os textos, as emendas (...). Não partimos de perguntas porque não queremos informação sobre algo, queremos compreender como o nosso colaborador articula a narrativa sobre sua vida. (2006, p. 31)
\end{abstract}

A verdade é que, por um lado, a opção "voluntarista" - que reduz a participação do entrevistador a "estímulos" - não pode ser prescrita como receita metodológica infalível. Adyel, ao analisá-la da perspectiva de quem narra, levanta só um problema entre outros: Será que essa "teoria voluntarista" não colide com os recursos limitados (de tempo, de recursos) a que nossas pesquisas geralmente estão submetidas? Fazer perguntas não seria uma maneira de evitar que a entrevista vague para lugares arriscados, inclusive do ponto de vista ético? O voluntarismo não falsearia a natureza e a finalidade da própria entrevista de história oral, cuja meta final é extrair informações, e não entabular uma amizade desinteressada?Por outro lado, com ou sem "voluntarismo", as entrevistas têm "personalidade", têm "inícios diferentes", têm "percursos (...) a partir do contar do colaborador": como Michael Frisch frisou há quase trinta anos, a entrevista de história oral é, por definição, fruto de "autoridade compartilhada", o que independe da decisão do entrevistador de "compartilhar autoridade". ${ }^{6}$ O começo da entrevista pública com Adyel é prova disso: ela ignora solenemente minha questão, para depois queixar-se da ausência de questões em nossas entrevistas anteriores.

Lembro-me bem das dificuldades de minhas primeiras entrevistas com Adyel. Só em nosso terceiro encontro senti-me "autorizado" (influenciado, ainda, pelo "voluntarismo") a partir para perguntas diretas. Os dois primeiros ajudaram em uma espécie de pesquisa formal: na edição de sua entrevista, preservei um pouco da dramaticidade oferecida pela postergação dos assuntos diretamente relacionados ao

\footnotetext{
${ }^{6}$ A esse respeito, ver o clássico livro de Michael Frisch, A SharedAuthority(1990), mas também sua réplica a um debate sobre suas ideias (2003), no qual esclareceu a diferença entre "autoridade compartilhada" e "compartilhando autoridade". Em texto publicado em língua portuguesa (2016), ele volta a remeter a essa distinção.
} 


\section{W memória}

tema da pesquisa. O texto final compila visões da narradora sobre o mundo, parte para questionamentos abstratos que permeiam toda a pesquisa, e em seguida alterna para um episódio relatado casualmente no primeiro encontro: ela contou ter sido desafiada pelo instrutor de remo, que praticava há pouco tempo, a sair sozinha, por quatro quilômetros de raia olímpica. "Ele me provocou. Sou o tipo da pessoa que, se você diz que não pode, eu vou e faço", disse, numa frase lapidar da qual foi extraído o título de sua entrevista. A narração do episódio, supostamente descartável à luz do que eu buscava discutir, foi preservada no texto final como um recurso metonímico, extensível à postura de Adyel diante da vida e das dificuldades profissionais. Ainda assim, a maior parte da entrevista discute o tema geral do projeto a partir da vivência de Adyel. Chegar a isso implicou fazer perguntas, dignificando a história oral como um método que pode efetivamente, e não só alusivamente, responder a problemas de pesquisa.

Perguntar significa também limitar as chances de que se mande mensagens cruzadas. Uma conversa livre demais pode levar o entrevistado a construir seu interlocutor como um novo amigo íntimo (o que falseia o caráter profissional e a destinação pública da entrevista), como um profissional despreparado (o que depõe contra nosso próprio ofício), como um terapeuta (atividade para a qual não estamos qualificados). É exatamente nesta encruzilhada que, em sua narrativa sobre o processo, Adyel posiciona o significado do narrar-se:

\footnotetext{
Eu entrei numa catarse, na verdade. Foi um... foi um movimento absurdamente de catarse. Ele virou meu psicólogo. Ele virou, assim, o meu... o meu... ah, eu não sei... Se eu estivesse lá em Israel eu iria para o muro. [Ele virou] meu muro! Virou meu muro! Não só de lamentações, porque virou também o meu muro, sabe?, de coisas bonitas. De coisas que estavam lá atrás, que eu já nem lembrava mais. Ele puxou essas coisas, né? Foram... foram várias... foram vários encontros. Foram várias histórias, foram várias... vários momentos que ele naquele "Fala..." provocou - de eu me lembrar, de eu me buscar, de eu reconhecer, de eu pensar e...
}

Dizendo que funcionei como seu "muro", Adyel constrói nosso espaço narrativo como um lugar seguro, protegido, até sagrado - o que entendi melhor tempos depois, na véspera do lançamento de Solistas Dissonantes, quando ela me telefonou confessando a preocupação de não ser bem compreendida pelos críticos e leitores comuns, preocupação impenetrável dentro dos limites do muro, no qual ela depositou confissões e 


\section{memória}

desejos sem hesitação. ${ }^{7}$ Acontece que os muros, acima de tudo, separam: "o muro é a comunicação cortada, com a sua dupla incidência psicológica: segurança, sufocação; defesa, mas prisão" (CHEVALIER, GHEERBRANT, 2009, p. 626). E, para o bem ou para o mal, muros podem ser derrubados - destino semelhante ao do diálogo íntimo artificializado da entrevista de história oral.

O "muro" é uma imagem metafórica forte, ratificada pela própria narradora. Mesmo não sendo só de lamentações (como um doloroso lugar de memória), também o é: a entrevista íntima abre espaço para a expressão do sentimento e, portanto, do ressentimento, da tristeza, da dor. Ao terminar gravações, já lamentei profundamente ter trazido à tona memórias dolorosas - especialmente porque quase nunca sabemos o que acontece depois que saímos de cena. Propomos aos nossos entrevistados uma nova relação com seu passado, e isso não é uma coisa simples.

Recentemente, entrevistei Mônica, uma mulher brasileira que narrou em detalhes um antigo relacionamento, incluindo informações de seus arranjos sexuais, que haviam falado alto para o fim da relação. Dois dias depois, a reencontrei para continuar a entrevista. Antes mesmo que o gravador fosse ligado, ela passou a retificar sofregamente cada uma das coisas que havia dito - revelando que as horas que sucederam nosso encontro tinham sido enormemente conflituosas, dilacerantes, fonte de ansiedade e medo. Seu equilíbrio emocional só foi restituído após a narração; e o fato de eu lhe ter assegurado que nada viria a público sem seu consentimento sugeria que suas retificações eram destinadas a si mesma: era daquela forma, e não da anterior, que ela deveria lembrar o pai de seus filhos.

Vários meses depois de enxergar-se em seu espelho narrativo - experiência mais complexa e profunda do que o despertar da consciência política que algumas vertentes de história oral propõem como sua missão -, Adyel pôde, em nossa descontraída entrevista sobre o processo de pesquisa, responsabilizar seu entrevistador (que, ao contrário de um

\footnotetext{
${ }^{7}$ Creio que o temor de Adyel não se confirmou e o esforço de compreensão característico da história oral também atuou em quem a leu. Outra entrevistada, a cantora Leila Maria, trouxe a preocupação dentro de sua própria entrevista: "Eu mesma não falo disso, porque tenho medo de que as pessoas não entendam o que estou dizendo e não apenas me tomem como preconceituosa, mas achem que estou usando isso como um recurso para justificar porque não acontecem mais coisas na minha carreira. Talvez enxerguem como um tipo de dor de cotovelo... Então, não dá. Não falo sobre isso com ninguém, porque as pessoas não assumem nem o preconceito geral - imagine, então, o especificamente aplicado dentro dessa área" (SANTHIAGO, 2009, p. 76-7). "Não falo sobre isso com ninguém", disse ela, mas falando comigo a respeito.
}

Revista Memória em Rede, Pelotas, v.10, n.18, Jan./Jul.2018 - ISSN- 2177-4129 
muro, interpela, interpreta e amplifica) pela exasperação que sucedeu a entrevista, responsabilização que em vários casos, como no de Mônica, permanece implícita:

Ele me deixou depois [pensando] assim: "Puta que pariu! Por quê que eu fui nascer preta, não cantar samba nesse país aqui, que não tem memória, que não se respeita, que não conta histórias pros seus filhos? Que merda que eu fui fazer?!? Que carma é esse?!?" (...) E... e eu tive momentos de grandes tristezas por causa desse menino.

Vários trechos de nossas entrevistas originais descortinam esse processo de descoberta. Um deles é particularmente significativo. Adyel falava sobre os convites recebidos por gravadoras após o sucesso que fez com o jingle-canção I Feel Good:

\begin{abstract}
[Alguém me disse:] "Eu saí dali com três propostas pra você, pra gente prensar isso como disco, entendeu? Fica nas tuas mãos, você escolhe". Mais uma vez eu escolhi errado... Puta que o pariu! Eu já tinha até esquecido disso! "Tem a Eldorado, tem a Warner, tem a não-sei-quem". Eu escolhi errado, eu fiz o raciocínio [contrário]. Puta que o pariu, como eu sou pobre! $\mathrm{Ai}$, por quê que eu fui lembrar disso agora? (...) Porra, Ricardo, eu falei: "Ó, quer saber, eu vou escolher a Eldorado, porque eu acho que, como ela tem um casting pequeno, ela vai poder me dar atenção". (...) Ai, agora eu tô com raiva de mim! Hoje eu vou remar com vontade! (...) Olha isso, que pobreza: você tem uma Warner, você tem uma multinacional na mão, e optar por uma coisinha pequena, aqui. Ah, não! Eu mereço tudo [de ruim]! Porra! Olha isso! Eu tinha até esquecido, esquecido! Mas tudo bem, tudo bem.
\end{abstract}

Em última instância, o que Adyel faz é requalificar o passado, atribuindo novos sentidos aos fatos que rememora, no ato da rememoração (ainda que sem requalificar sua própria agência, sua capacidade decisória). É para um entendimento mais profundo de "liberdade narrativa" que esse procedimento aponta. Robert Zussman (2012) definiu "liberdade narrativa" como "a capacidade de contar histórias sobre nós mesmos da maneira como queremos, não simplesmente reunindo determinados fatos e eventos, mas extraindo significados e lições sobre nossas próprias vidas". Isso se dá por meio de "processos de seleção e conexão, atos de construção imaginativa que são a base para a narrativa" (p. 808). Nessa perspectiva, a "liberdade narrativa" que caracteriza o diálogo da história oral não se subsume às "condições sociais sob as quais a liberdade narrativa é possível" (ZUSSMAN, 2012, p. 810), à garantia de que o narrador possa pura e simplesmente "dissertar o mais livremente possível sobre sua experiência pessoal" (MEIHY, 2002, p. 131) Ela se realiza, principalmente, conforme a qualidade dessa, 


\title{
We memória
}

digamos, dissertação: enquanto um trabalho de memória reativo (que reage à demanda externa para narrar, ao contrário do que ocorre em outros tipos de reconstrução autobiográfica) e criativo (que implica seletividade, atribuição de significado, convencionalização e reconvencionalização linguística).

\section{5. "Agora já estou pronta para falar..."}

Além de contar sobre nossa relação, Adyel também se valeu da ocasião para recontar aquilo que já havia verbalizado em nossos encontros privados, executando um ato autobiográfico distinto. Ainda na primeira metade de nossa conversa, ela disse:

\begin{abstract}
Eu fui apresentadora de um programa de televisão que aconteceu num período de um ano. ${ }^{8} \mathrm{E}$ uma coisa que eu vivia falando para as pessoas: contem as histórias das suas famílias. Conta a história da sua avó! Lembra as histórias que a tua avó, o teu avô - as histórias [que eles contavam], sabe? De onde você vem. Conta isso para os teus filhos! Eu conto para o meu. Para ele ter mais consciência do que ele é, do que ele tem, do que ele pode. Eu acho que fica mais fácil quando a gente se... quando a gente se conhece, se reconhece e, sabendo das histórias, explica. É... é isso... Deixa ele falar um pouco para mim... Eu vou me inspirando...
\end{abstract}

Adyel conectou passado (o tempo da memória)e presente (o tempo da narração, o tempo do nosso projeto compartilhado) na narrativa, em renovada valorização. Em seguida, abandonou o assunto (o estímulo à contação familiar, que mais adiante vamos retomar), conclamando minha intervenção. "Agora eu fico numa situação difícil”, respondi - pego de surpresa, mas pretendendo continuar. A plateia riu; e Adyel recuperou o controle narrativo de imediato, suspendendo sua reticência. Sabia onde chegar, mas o caminho se construiu ali: "Eu contei pro Ricardo, por exemplo, que... Tá vendo como é que é? Agora tenho que voltar, e voltar, e voltar para vocês entenderem".

Percorrendo os vários tempos da memória, ela reconta a história de seu famoso pai, Adhemar Ferreira da Silva. Profetiza que ela se perderia, que já estaria se perdendo e a repete (sem nomeá-lo) para que não a esqueçamos:

\footnotetext{
${ }^{8}$ Trata-se do programa "Encontro da gente", apresentado em 2005 e 2006 na TV da Gente, idealizada pelo cantor Netinho de Paula como uma emissora voltada ao público negro.
}

Revista Memória em Rede, Pelotas, v.10, n.18, Jan./Jul.2018 - ISSN- 2177-4129 
Eu sou filha de um homem que o Brasil já não lembra mais. E daqui a mais duas Olimpíadas então, acabou! Meu pai atravessou o século XX como o único brasileiro com duas medalhas olímpicas e de atletismo. Bobagem? Pode ser. Mas não é bobagem não. Não é bobagem por ele ser... Ele teve a sorte de descobrir no esporte - e eu estou falando da década de [19]40 - de descobrir um esporte e, num esporte, descobrir um jeito de buscar lá na frente um futuro. Talvez nem para ele, mas para os filhos e para o neto e para quem mais vier. Por causa do esporte ele deixou, talvez, de ser um bandido, um ladrão, um assaltante, um assassino, sei lá o que...

Então, ela contou sobre as experiências - privilegiadas - proporcionadas à filha de Adhemar: ganhar uma formação cultural sólida e eclética, viver na Nigéria (onde o pai foi adido cultural do Brasil) e com isso aprender a falar inglês, adquirir um capital cultural que Ihe permitiu participar de círculos culturais de prestígio. Contou sobre a outra face desta mesma moeda: sentir-se estrangeira na vida cotidiana ("Eu comecei a ter dificuldades de ser também aceita por um grupo e por outro, tanto para os brancos quanto para os negros. Em comum eu tinha a coisa de ser a neguinha metida") e na vida artística ("É complicado, assim... Eu não me... Tem hora que eu não sei... Também eu não sei se precisa de uma pessoa estar inserida em algum nicho, sabe?).

Falas certeiras embaralham-se a sentenças espasmódicas, na representação exata do trabalho de memória e linguagem desenvolvido na entrevista de história oral. Em meio a falsos inícios, frases incompletas e autorretificações, aparecem segmentos mais elaborados, arrematados - aqueles "episódios", "contos contados duas vezes", como escreveu Portelli, que representam um "esforço pessoal de composição na performance" (2001, p. 12). Ocorre que na maioria das vezes temos acesso apenas ao ponto culminante desse esforço, e não conseguimos fazer mais do que especular a respeito das diferentes ocasiões sociais em que um episódio supostamente cristalizado foi submetido a teste.

Depois de "voltar, e voltar, e voltar", mergulhando na história de sua família, Adyel retomou o fio interrompido em "Eu contei pro Ricardo, por exemplo, que...". Alegou estar bastante emocionada, mas insistiu em contar uma história - uma história emblemática, que eu já havia escutado, mas que não estava lhe pedindo para repetir. A autoridade narrativa, estava claro, não era minha, como também não era minha a autoridade sobre o caráter especialmente performático daquela entrevista: 
[O que quero contar é] a história da minha avó. A história da minha avó é uma história muito bonita. Eu acho que eu já estou mais forte para poder contar para vocês. Ô meu Deus...! Eu era pequena e morava no Rio de Janeiro. (...) Meu pai trouxe uma televisão, e tinha o Teatrinho Trol, que era um programa infantil que todo domingo passava. Era tão bonita a abertura - era uma bailarina com aquela sainha... aquele tchutchu com ponta... É lindo, né? Eu acho lindo! Eu acho bonita até hoje a figura da bailarina, assim, uma coisa romântica - igual na música, o saxofonista tocando ali embaixo do poste com luz... É uma coisa bacana! Eu queria ser bailarina. Agora, imaginem vocês que a minha avó...

Mais uma vez, o humor: em vez de completar a frase, Adyel se levanta, de maneira propositalmente desengonçada, e corre as mãos pelo corpo (belo, atraente, mas distante da esguiez típica de bailarinos) em simetria, como se dissesse: "Agora, imaginem vocês que a minha avó... logo percebeu que com esse corpinho eu não conseguiria ser bailarina". A plateia desabou em risos; a competência de Adyel para emaranhar conteúdo semântico e somático, para executar um tipo específico de performance verbal (diferente da performance do canto e do teatro, em que atua como profissional) estava dada. Manejando o timing da comédia, Adyel prosseguiu, segundos depois, recorrendo mais uma vez à estratégia de suceder o riso com uma asserção séria:

As avós da gente são tão sábias! A minha avó teve um insight.

Eu não pedia para ela, eu pedia para os meus pais: "Papai, eu quero ser bailarina. Mamãe, eu quero ser bailarina". (...) [Mas] não tive sapatilha coisa nenhuma! No meu quinto aniversário, encosta um caminhão da Lusitana, e desceram um piano lá na minha casa.Eu fiquei louca! Detestava! Eu ficava olhando praquilo de longe... uma coisa pesada... de longe... Sapatilha era um negócio tão mais levinho, elegante! [risos da plateia] (...) Que saco! Aí eu fui obrigada e estudar piano. Fui obrigada! Estudei! (...) Minha avó fez uma força enorme pra... pra me dar esse piano. Ela comprou nas Casas Manon, que era uma das únicas casas aqui em São Paulo onde se podia comprar um piano. Comprou um piano alemão... e eu detestava mesmo. Detestava. Ainda hoje, sabia? (...) Mas acabei o curso. Fechei o piano e nunca mais.

Eu tenho que falar de novo que a minha avó teve um insight: que eu não nasci para ser bailarina e que talvez a grande coisa da minha vida seria a música. Mas eu acho que, principalmente, ela achava que o piano... Toda moça boa, toda moça fina, estudava piano. Ela... ela foi lavadeira muito tempo, e meu pai, quando era garoto, ajudava a minha avó a carregar trouxas de roupa limpa e passada da Casa Verde para Higienópolis. Eu contei isso para o Ricardo. Está aqui... [aponta para a transcrição da entrevista]Minha avó entrava pelas portas dos fundos desses apartamentos e casas em que hoje eu entro pela frente sempre. É...Eu acho que quando ela ia levar essas roupas ela via ou ouvia um piano. Ela não via, porque não tinha o direito de entrar nas salas. Mas ela ouvia, lá do fundo, o piano... E, amorosamente, ela me deu esse piano, [como se quisesse dizer] assim: "Espero que você se dê bem na vida". Acho que foi isso. Fundamentalmente isso. Por isso me emociono quando eu falo... quando eu falo... 
"Eu contei isso para o Ricardo", disse Adyel. "Eu contei pro Ricardo, por exemplo, que...", ela já havia dito. "Está aqui...", ela insistiu, apontando para a versão escrita de nossos diálogos. Em suma: ela lembrou o fato e lembrou igualmente a narração do fato; o ato da entrevista, a corporificação textual do episódio contado; um momento, talvez, de 'triturar as suas 'cerâmicas biográficas', desmanchando a tal substância pré-existente e permitindo, assim, a emergência de outras figuras, formas, dimensões e sensações ainda não enunciadas e materializadas", como escreveu Daisy Perelmutter (2016, p. 103-4) a respeito da história oral como "coisa séria", como um "investimento estético que aspira à invenção da realidade, e não à sua calcificação" (p. 118).

"Eu acho que já estou mais forte para poder contar para vocês"; "me emociono quando eu falo... quando eu falo..."; "agora já estou pronta pra falar": Adyel expande o significado que teve, para ela, a articulação (em nossa entrevista, uma narração com destinação pública) de uma história de família em princípio como tantas outras, assinalada por frustração e mal entendido. Se ela precisou esperar até sentir-se pronta para repeti-la, isso se deve, provavelmente, à avaliação de que o significado poético e existencial que extraiu de sua própria narração/narrativa não obscureceu a ladeira íngreme que lhe permitiu chegar lá. O público, afinal, foi contemplado com uma "narrativa pregnante" dotada de inegável "força estética" (ALBERTI, 2004, 2008), sensivelmente distinta do processo de compreensão da experiência, inédito e trepidante, que nossos diálogos privados anteriores documentam. Em sua casa:

\footnotetext{
... e aí no meu aniversário, minha avó, chega lá um caminhão da Lusitana com esse piano...

Esse, já? [o entrevistador aponta para o piano]

É.

Com sete anos?

Com cinco anos. Meu aniversário de quinto ano.

Ah, achei que era um pianinho...

Nãoooo! Isso aí! Eu fiquei puta da vida! Fiquei olhando praquela coisa - já é grande, mas naquela época eu era menor, então era maior ainda -, falando: não era isso que eu queria. Eu queria uma sapatilha! Que eu faço com isso?

Aí foi obrigada a estudar piano.

Mas era uma coisa louca, né, porque talvez a minha vó tenha tido um insight. Louco isso, né? Porque eu nunca, nunca mostrei pra ninguém que eu gostava de música, né? Eu não tinha esse interesse. Nada disso. Aí fui obrigada a estudar piano. Ai, que horror!

Mas por que você acha que sua avó te deu isso?

Não sei! Não sei!

Da cabeça dela?
} 
Talvez da cabeça...

Em privado, havíamos chegado naturalmente a um episódio em pedaços, derivado de um anárquico trabalho de memória; em público, chegamos deliberadamente a uma narrativa una, derivada do impulso determinado da narradora, que encapsula esse conto e confirma que os narradores trabalham continuamente enquadrando e reenquadrando seus textos, em conteúdo e forma. A fluidez apresentada na entrevista pública está ausente da gravação original, na qual as perguntas funcionaram como picaretas, rompendo aquelas "cerâmicas biográficas" de Perelmutter e dando acesso a um novo terreno de significados. As questões funcionam como fios de sutura absorvíveis cosendo fragmentos de sentido num conto unificado, para depois tornarem-se imperceptíveis a olho nu.

Nesse sentido, a história contada para mim e transposta para o papel parece ter sido uma espécie de rascunho para uma "narrativa pregnante" - aperfeiçoada, cristalizada e apresentada meses depois, já em uma estrutura julgada como convincente, cativante e transportável. O aparecimento desse episódio na entrevista pública é revelador: ele não emerge encadeado a um fluxo narrativo natural, mas é extraído de seu contexto original e inserido, porque autocontido, em uma nova narração autobiográfica, como num processo de sampleamento, anunciado pelo: "Agora já estou pronta pra falar".

É preciso lembrar que, nesse ínterim, a narradora teve uma convivência intensa com as próprias lembranças, nos interstícios de nossas múltiplas sessões. Mais importante: ela havia lido, dias antes, a versão textual das entrevistas, que pode ter sido a prova dos nove para a confirmação de que o conto "funcionava" mesmo se alijado de sua ambientação original (a sala de estar, as fotografias, os livros e, é claro, o piano): "Está aqui", lembremos. "Esse, já? Com sete anos?", perguntei, por estar diante do objeto biográfico. Para "funcionar" em outro ambiente, provocando o mesmo impacto, o rascunho passa por um processo de adaptação, aperfeiçoamento e cristalização: um processo que a entrevista sobre o processo ajudou a visualizar.

O caso, porém, é complexificado em função do expediente que utilizei no tratamento da entrevista: a transcriação. Sendo um processo de estabelecimento textual que atenta menos para as palavras tais quais pronunciadas e mais para a recriação literarizada da situação comunicacional, ele exige a participação do narrador também

Revista Memória em Rede, Pelotas, v.10, n.18, Jan./Jul.2018 - ISSN- 2177-4129 


\section{memória}

como revisor do texto final, que ele deve conferir e autorizar, manifestando reconhecer-se nos escritos elaborados com relativa liberdade pelo pesquisador. Para mim, a transcriação sempre equivaleu essencialmente a uma edição aguda da entrevista, comportando a eliminação de perguntas, que gera um texto em primeira pessoa; a reorganização temática do texto; a supressão de passagens; o uso ostensivo da pontuação como recurso expressivo. Hoje, por muitas razões, já não utilizo esse dispositivo - e tenho consciência de que ele introduz no texto informações estranhas às trocas intersubjetivas que têm lugar na situação de entrevista. ${ }^{9}$

Entre a narrativa entrecortada da história oral privada e a narrativa pregnante da história oral pública, Adyel teve acesso a uma reconvencionalização da sua experiência feita por ela, no ato da narração, mas também por mim, no ato da transcriação (SANTHIAGO, 2009, p. 42-3). Pôde, nesse ínterim, olhar-se a partir de fora, objetivada em um texto cujos efeitos abateram-se também sobre ela, sua primeira leitora: além de se relacionar com a construção que fez de sua própria história, relacionou-se com as decisões formais tomadas por mim no estabelecimento daquele texto.

Que fenômeno, então, teria condensado sua fala, dimensionado o significado simbólico da história de sua avó, levado a narradora a qualificar aquele episódio como digno de ser repetido: a experiência da narração ou a leitura de um texto cujo encadeamento o inunda de dramaticidade?Esta é uma pergunta complicada, talvez irrespondível - e, a meu ver, o simples reconhecimento de que a história oral é fruto de um trabalho compartilhado, com autoria e autoridade compartilhadas, não satisfaz.

Sobre isso, um último comentário: Adyel é uma artista, e são sobretudo os artistas, continuamente convocados a falar sobre si e sua obra, os mestres em cristalizar pedaços de histórias, formando um repertório de fragmentos narrativos pronto para ser reutilizado. As várias maneiras de rememorar e narrar uma experiência convergem para uma só, quando esta se mostra eficaz - e é ela (e não a experiência, em si) a matriz de novos textos. "Natural" ou "artificial", "fresca" ou "cristalizada", a narrativa deriva da autoridade do narrador, capacitado e autorizado para montar, editar, reproduzir ipsis litteris, ipsis verbis, sua fala. A tarefa do analista não é a de distinguir o joio do trigo, atribuindo aos

\footnotetext{
${ }^{9}$ Para mais informações sobre a transcriação, ver: MEIHY, 2005. Críticas desse procedimento, em outras bases, estão disponíveis em, por exemplo: LEITE, 2008; SANTHIAGO, 2011.
}

Revista Memória em Rede, Pelotas, v.10, n.18, Jan./Jul.2018 - ISSN- 2177-4129 
relatos pessoais graus variáveis de autenticidade, mas a de compreender a função que os fragmentos cristalizados cumprem dentro de uma construção biográfica ampla.

\section{Histórias de família}

"A história da minha avó" crava na biografia de Adyel um senso de continuidade. Primeiramente, familiar: passa pelos sonhos da avó e das possibilidades abertas pelo famoso pai. Por extensão, continuidade artística: o piano funciona como símbolo de sua inserção em uma tradição estética inaugurada por Alaíde Costa, cuja vida é marcada também pela presença (primeiro enquanto presença ausente) do instrumento. A própria Adyel já havia me dito, nas nossas primeiras entrevistas: "Se eu for herdeira de uma tradição negra, gostaria de ser herdeira da tradição que a Alaíde trouxe, sendo rigorosíssima com repertório, abrindo um caminho e marcando essa outra faceta do negro" (SANTHIAGO, 2009, p. 61).

Ela sente raiva da avó - por ter the dado um presente que não queria, tendo the imputado a primeira grande responsabilidade (indesejada) de sua vida. Adyel cumpre sua sina e forma-se no Conservatório Dramático Musical, uma das escolas mais prestigiadas de São Paulo, dentro de uma perspectiva fundamentada no repertório romântico, predominantemente europeu, do século XIX. Tornando-se cantora popular, jamais se apresenta em público tocando o instrumento. A contrariedade dos tempos de infância é rememorada, bem mais tarde, sob outro ângulo. E a história oral é textualmente reconhecida, na metaentrevista de Adyel, não tanto como um instrumento de amplificação de vozes alegadamente abafadas, mas como um processo de ressignificação privada da própria história. Está em jogo, para ela, o legado familiar e suas formas de preservação:

\footnotetext{
O que a gente não pode é esquecer essas histórias que a gente ouviu e que a gente vive... O que a gente viveu, o que a gente sentiu. E é importante a gente... é muito importante a gente contar isso para as pessoas que estão próximas da gente, sabe? Porque essas histórias vão continuar. Eu contei pra ele [Ricardo]. Eu conto para o meu filho. Se eu não tivesse um filho e tivesse contado pra ele [Ricardo], eu tenho certeza que daqui a cem anos alguém [poderia estar] contando um causo [sobre mim], em função de contar essas histórias. Elas não são bobas não! Não são só os homens poderosos que fazem história. A gente faz história todo dia. Ele [Ricardo] me valorizou. E eu valorizei a minha avó na hora que eu contei isso pra ele. Porque eu contei de todo o trabalho que ela teve, o quanto ela suou e quanta esperança ela colocou - o quanto ela quis que eu não
}

Revista Memória em Rede, Pelotas, v.10, n.18, Jan./Jul.2018 - ISSN- 2177-4129 
tivesse a vida dela, entendeu? - naquele piano, na figura daquele piano. Para ela, era a chave de entrada num mundo que ela não teve.

E, narrando-se mais uma vez depois de tantas outras, Adyel continua perscrutando seu passado, em um processo de reinterpretação que não arrefece. Há várias pistas textuais que indicam que sua nova fala, embora decalcada das narrações anteriores, está sendo construída em presença: a lembrança das entrevistas passadas funciona como uma espécie de muleta narrativa que the proporciona fazer novas conexões. Em alguns desses casos, ela nos mostra que a capacidade de mobilizar novos significados não se deteriora nem mesmo quando um fragmento narrativo está cristalizado. Ela arrisca, inclusive, uma reavaliação:

\footnotetext{
Contando isso eu já nem sei se a história do meu pai é tão importante para eu ter me voltado para a música. Porque é... Ela [minha avó] faria [a mesma coisa] de qualquer maneira: com o filho dela campeão ou não, tenha tido [ou não] a chance de ir morar na Nigéria e representar esse país por causa de não-sei-o-que.
}

"A gente está falando de história oral. Eu acho que todo mundo deveria ter a oportunidade de fazer a história oral da sua vida, não é? Fazer, falar...", diz mais adiante uma mulher da plateia, visivelmente emocionada. Adyel concorda, mas à sua maneira: em vez de sugerir que todos deveriam ser objeto de estudo e interesse acadêmico, retoma sabiamente o que já havia sugerido antes (como se vê na primeira citação reproduzida neste artigo). Lá, ela relatava que, durante seu período como apresentadora de TV, lançava mão de um meio de comunicação massiva para estimular a transmissão intrafamiliar e intergeracional de histórias: "vivia falando para as pessoas: "contem as histórias das suas famílias'”. Desta vez, agregou humor à sua fala:

\footnotetext{
Contem para os seus filhos, para os seus sobrinhos, para os seus netos. Contem suas histórias, as histórias dos seus pais e as histórias dos seus avós. Isso é muito enriquecedor. Isso é fantástico. Tem que contar história. Devia ser assim, ó: não tem a Hora do Brasil? A gente devia fazer a "hora da gente". Marca [hora], bota [todo mundo] ali sentado e conta! [risos da plateia]
}

Curiosamente, ela se vale de uma referência ao programa radiofônico Hora do Brasil (hoje $A$ voz do Brasil), subvertendo-o: quando foi instituída a obrigatoriedade de sua retransmissão por todas as emissoras de rádio do país, em 1938, o Departamento 


\section{We memória}

Nacional de Propaganda (DNP) da ditadura getulista preenchia seus sessenta minutos de duração com discursos do presidente e anúncios dos atos executivos. Adyel rasura o significado da "hora" em que todo o "Brasil" entra em sintonia, mobilizando-a como metáfora política para valorizar o poder político das histórias: quer uma pluralidade de vozes em vez do discurso unívoco; o intercâmbio pessoal em vez da comunicação massiva, unidirecional; a liberdade de expressão em vez da informação restrita.

Para ela, a transmissão familiar de histórias não tem um caráter apenas de curiosidade, de passatempo. "Para ele ter mais consciência do que ele é, do que ele tem, do que ele pode" - é por isso que Adyel diz contar as histórias de família para seu filho, Diego, que como trabalho de conclusão de sua graduação em Rádio e TV produziu um vídeo-documentário sobre o avô. Ela, no entanto, não espera que suas compreensões da história familiar coincidam:

\footnotetext{
Mas eu acho que, se você perguntar para o meu filho, se você der a chance para o meu filho falar, eu não sei se ele vai falar isso tudo. Ele já vai falar sob o olhar dele, a vivência dele, que é uma outra coisa. Acho [que] a coisa importante de sempre falar, de contar, é... não sei... Eu supervalorizei a minha avó depois disso tudo, entendeu? É contar para vocês de eu onde eu venho e me conscientizar de quem eu sou, do que eu estou fazendo, do quê que eu quero.
}

O passado familiar é para Adyel, enfim, uma bússola poderosa: a intuição que atribui à avó confere a ela os meios (e a responsabilidade) para seguir adiante; e a história oral, neste caso, parece ter sido o instrumento que the permitiu reinterpretar - e não simplesmente relembrar - essa história, em um processo de pesquisa compreendido em sua plenitude, do modo que só uma entrevista sobre o processo permite vislumbrar.

\section{Amigos, amigos... História oral à parte?}

Ecléa Bosi - cujo trabalho é e continuará sendo esteio dos mais floríferos para a prática da história oral - disse certa vez que toda entrevista resultaria desejavelmente em uma amizade. Bem, mas isso seria exequível? Seria desejável? Como cultivar tantas amizades depois da segunda dezena de entrevistas? Como não desvirtuar a vocação da investigação - será que não acabaríamos elegendo como narradores apenas as pessoas com quem supomos afinidades prévias, impedindo o intercâmbio e a aprendizagem que 


\section{Memória}

caracterizam uma entrevista? Ecléa, é claro, estava longe de propor a amizade como regra - queria lembrar que ela pode ser abraçada, estando no nosso horizonte de possibilidades.

Cada entrevista é uma nova relação e uma relação única. Mas todas elas são também um decalque de relações anteriores. Em "Para além da entrevista: Uma autoetnografia da minha prática", Alessandro Portelli (2016) disse ter sido "filho" de Dante Bartolini e "irmão" de Annie Napier em seus projetos sobre as Fossas Ardeatinas e sobre o Harlan County, respectivamente. Em minhas entrevistas eu já fui filho, irmão, e muitas vezes neto - mas a implacável passagem do tempo vem me privando dessa possibilidade. O modelo de minha relação com Adyel foi o de uma amizade - que antes de nossas entrevistas já estava em estado latente. Foi isso, e não o dogma da colaboração em história oral, que permitiu nossos vários compartilhamentos.

$\mathrm{Na}$ maior parte das minhas experiências, neste e em outros projetos, a colaboração não ultrapassou a duração das entrevistas: exprimiu-se como um trabalho de memória que cooperou para a ampliação do conhecimento sobre certo assunto. Para isso, um grau profundo de colaboração não é imprescindível. Em outros casos, a entrevista possibilitou o reconhecimento de repertórios complementares, visões afinadas, propósitos parecidos - desdobrando-se em compartilhamentos posteriores à, e independentes da, entrevista. Isso me ensinou que a colaboração em história oral se dá em graus diferentes, como resultado da interação humana e da autoridade compartilhada da entrevista, e não como efeito de um discurso metodológico prescritivo.

Com Adyel, muitos foram os compartilhamentos. Por força das circunstâncias, estamos hoje um pouco afastados, é verdade, mas ainda ao alcance do ouvido: sua história me habita. Fomos e somos cúmplices em visões de mundo e crenças profundas, em intercâmbios de estímulos e conselhos. Eu estive com ela e ela esteve comigo em momentos importantes. Nosso trabalho colaborativo acompanhou um processo de modificações profundas na minha vida e também na dela. Mais de uma vez me senti devedor por não conseguir corresponder a todas as suas expectativas, e talvez por isso eu venha tendendo a praticar um distanciamento cautelar de meus mais recentes entrevistados. Reconhecer que nem sempre é possível manter compromissos após a pesquisa é um peso; e dói.

Revista Memória em Rede, Pelotas, v.10, n.18, Jan./Jul.2018 - ISSN- 2177-4129 
A história pública, a meu ver, é uma forma de amainar esse conflito: "amplificar as vozes" dos nossos entrevistados, colocando-as em circulação e discutindo-as criticamente, sem abdicar da independência intelectual e da integridade da pesquisa, parece ser um plano melhor do que nos penitenciarmos repetidamente por tudo aquilo que não podemos fazer. No entanto, a segunda opção parece ter sido mais frequentemente seguida, como o artigo de Anna Sheftel e Stacey Zembrzycki (2016) sobre "cinquenta anos de debates e angústias sobre ética" mostra.

Mais de uma vez, o trabalho que realizei com essas cantoras - que teve repercussão imprevista - foi invocado por elas mesmas como algo capaz de "autenticar" suas próprias colocações e de demonstrar o caráter social de percalços tão facilmente atribuídos a questões individuais ou a acidentes de percurso. O maior mérito do trabalho certamente foi este: o de colocar em circulação e tornar visualizável um problema de difícil formulação. No fim das contas, até por isso a preocupação que Adyel demonstrou, em sua entrevista pública sobre o processo, seja justificada. Quando Ihe perguntei sobre sua reação ao ler seu relato transcrito e editado, ela reagiu:

\begin{abstract}
Olha, no dia que você me deu o texto escrito, a transcrição do que eu falei, [eu pensei:] "Quanta bobagem!" [risos do público]. Eu falei: "Meu Deus, eu posso não ter falado isso? Por quê que eu falei isso?". (...) Eu fui super verdadeira, mas eu tenho que tomar cuidado, porque isso pode vir a público e... Eu sou formada em jornalismo. Eu conheço a raça! [risos] E eu não posso cutucar. Sem cutucar, eles já me tratam com um pouco de desprezo. Se se sentirem cutucados, vai ser bem pior. Pra quê? Pra quê, né? (...) Aqui, lendo, eu pude... eu pude ver como eu viajo, né? Eu falo: "gente, eu comecei aqui, mas eu não concluí". (...) Também porque faz muito tempo, né? Isso foi [falado] há três anos. Aí, quando eu li, eu fiquei emocionada com algumas coisas. E por duas vezes eu parei de ler. Eu falei: "Eu vou parar de ler". Talvez eu não estivesse num momento feliz, muito confortável, estivesse fragilizada. (...) E você vai... É uma coisa de alma, mesmo, de se despir de tudo, de ter a chance de... "Fala..." de falar! É isso.
\end{abstract}

Assim como as histórias individuais são janelas para questões mais amplas, a narrativa de Adyel sobre sua experiência enquanto entrevistada levanta problemas procedimentais e éticos que são comuns à prática da história oral como um todo. Ela permite confirmar que não apenas nós, pesquisadores, somos capturados pela magia de um diálogo intenso. Permite entrever os desdobramentos das conversas que temos com nossos entrevistados, que vão da cristalização de fragmentos narrativos que voltarão a ser contados à solidificação de uma relação saudável com o passado. Permite, também, 


\section{memória}

relembrar aquilo que a prescrição metodológica quase nos faz esquecer: os princípios que supomos embasar nossas práticas profissionais e as técnicas que adotamos não garantem o sucesso de uma entrevista. Do lado de lá, a vista é outra.

\section{Referências}

ALBERTI, V. 'Narrativas pregnantes' como 'jogos de linguagem': Possibilidades da história oral à luz da teoria da linguagem de Wittgenstein". História Oral, v. 11, p. 127-48, 2008.

ALBERTI, V. "Além das versões: Possibilidades da narrativa em entrevistas de história oral". In: Ouvir contar: Textos em história oral. Rio de Janeiro: Ed. FGV, 2004. p. 77-90.

CHEVALIER, Jean, GHEERBRANT, Alain. Dicionário de Símbolos: mitos, sonhos, costumes, gestos, formas, figuras, cores, números. Rio de Janeiro: José Olympio, 2009.

FOSL, C. Subversive Southerner: Anne Braden and the Struggle for Racial Justice in the Cold War South. Lexington: University Press of Kentucky, 2006.

FRISCH, M. "A históriapúblicanão é uma via de mãoúnica, ou, De A Shared Authority à cozinha digital, e vice-versa" In: Mauad, A. M.; Almeida, J. R.; Santhiago, R. (org) Históriapública no Brasil: Sentidos e itinerários. São Paulo: Letra e Voz, 2016.

FRISCH, M. "Commentary - Sharing Authority: Oral History and the Collaborative Process". The Oral History Review, v. 30, n. 1, p. 111-3, 2003.

FRISCH, M. A Shared Authority: Essays on the Craft and Meaning of Oral and Public History. Albany: State University of New York Press, 1990.

HOLANDA, F. "Construção de narrativasemhistória oral: embusca dos narradoresplenos". Oralidades, v. 6, 15-32, 2009.

KIND, L.; Cordeiro, R. (org.) Notícias da vida: Narrativas sobre a morte com mulheres trabalhadoras rurais e mulheres vivendo com HIV/Aids. São Paulo: Letra e Voz, 2016.

KOTRE, J. "A verdade e a utilidade das histórias". In: Santhiago, R.; Magalhães, V. B. (org.) Depois da utopia: A história oral em seu tempo. São Paulo: Letra e Voz/Fapesp, 2013.p. 29-38.

LEITE, T. A. "O dilema da interferêncianahistória oral: Novosproblemas e novasrespostas". Oralidades, v. 3, p. 65-82, 2008.

MEIHY, J. C. S. B. Manual de história oral. $3^{\underline{a}}$ ed. São Paulo: Loyola,2002.

MEIHY, J. C. S. B. Manual de história oral. $5^{a}$ ed. São Paulo: Loyola, 2005.

Revista Memória em Rede, Pelotas, v.10, n.18, Jan./Jul.2018 - ISSN- 2177-4129 
MÜHLHAUS, C. Por trás da entrevista. Rio de Janeiro: Record, 2007.

NORRICK, N. R. "Humour in Oral History Interviews". Oral History, v. 34, n. 2, p. 85-94, 2006.

PERELMUTTER, D. "A História Oral como laboratório de sensibilização estética: Memórias e marcas de artistas brasileiros de ascendência judaica". In: Santhiago, R. (org.) História oral e arte: Narração e criatividade.São Paulo: Letra e Voz, 2016. p. 10118.

PORTELLI, A. "História oral como gênero". Trad.: M. T. J. Ribeiro. Rev. técn.: D. R. Fenelon. Projeto História, v. 22, p. 9-36, 2001.

PORTELLI, A. "Para além da entrevista: Uma autoetnografia da minha prática". In: História oral como arte da escuta. Trad.: R. Santhiago. São Paulo: Letra e Voz, 2016.

SANTHIAGO CORRÊA, R. Entre a harmonia e a dissonância: História oral de vida de cantoras negras. Dissertação de Mestrado - História Social. Universidade de São Paulo, 2009.

SANTHIAGO, R. "If you know Portuguese you know what this is': O papel da traduçãonahistória oral do Brasil”. In: Santhiago, R.; Magalhães, V. B. (org.) Memória e diálogo: Escutas da Zona Leste, visõessobre a história oral. São Paulo: Letra e Voz/Fapesp, 2011. p. 137-152.

SANTHIAGO, R. Solistas dissonantes: História (oral) de cantoras negras. São Paulo: Letra e Voz, 2009.

SHEFTEL, A.; Zembrzycki, S. "Who's Afraid of Oral History? Fifty Years of Debates and Anxiety about Ethics". The Oral History Review, v. 43, n. 2, p. 338-66, 2016.

SHOPES, L. "A evolução do relacionamento entre história oral e história pública". In: Mauad, A. M.; Almeida, J. R.; Santhiago, R. (org.) História pública no Brasil: Sentidos e itinerários. São Paulo: Letra e Voz, 2016. p. 71-84.

SLOAN, S. "On the Other Foot: Oral History Students as Narrators". The Oral History Review, v. 39, n. 2, 2012,p. 298-311.

SMITH, R. C. "História oral na historiografia: Autoria na história". In: Santhiago, R.; Magalhães, V. B. (org.) Memória e diálogo: Escutas da Zona Leste, visões sobre a história oral. São Paulo: Letra e Voz/Fapesp, 2011. p. 153-60.

VANGELISTA, C. "Histórias de vida e controle social: Experiências de pesquisa". Oralidades, v. 3, p. 15-25, 2008.

ZUSSMAN, R. "Narrative Freedom”. Sociological Forum, v. 27, n. 4, p. 807-24, 2012.

Revista Memória em Rede, Pelotas, v.10, n.18, Jan./Jul.2018 - ISSN- 2177-4129 